\title{
Management of sleep apnea in adults - functional algorithms for the perioperative period: Continuing Professional Development
}

\author{
Edwin Seet, MBBS • Frances Chung, MD
}

Received: 18 March 2010/Accepted: 2 June 2010/Published online: 4 August 2010

(c) Canadian Anesthesiologists' Society 2010

\begin{abstract}
Purpose Obstructive sleep apnea (OSA) is defined by repetitive partial or complete upper airway obstruction characterized by episodes of breathing cessation during sleep. It is the most prevalent of sleep disorders, seen in about one in four males and one in ten females. We reviewed current literature, collated expert opinion, and synthesized protocols from several institutions to present practical principles and functional algorithms to assist the anesthesiologist in the perioperative management of known and suspected OSA.

Principal findings Patients with OSA may have an increase in postoperative adverse respiratory events, sustained arrhythmias, hypertension, and other cardiovascular events. The gold standard for the diagnosis of OSA is polysomnography. The Berlin questionnaire and the American Society of Anesthesiologists OSA checklist are useful screening tools, while the STOP and the STOP-Bang questionnaires are easy to use in adults. Patients scheduled for elective major surgery, who are at high risk of OSA with significant comorbidities, may be referred for preoperative polysomnography. Perioperative precautions, such as anticipation of a possible difficult airway, use of short-acting anesthetic agents, avoidance of opioids, and extubation in a
\end{abstract}

\section{E. Seet, MBBS}

Departments of Anesthesia, Alexandra Health Private Limited,

Khoo Teck Puat Hospital, Singapore, Singapore

F. Chung, MD ( $\square)$

Department of Anesthesia, University Health Network,

399 Bathurst St. McL 2-405, Toronto, ON, Canada

e-mail: Frances.Chung@uhn.on.ca

F. Chung, MD

University Health Network, University of Toronto,

Toronto, ON, Canada non-supine position, should be undertaken for known or suspected high-risk OSA patients. Postoperative disposition of the OSA patient should be based on the severity of the sleep disorder, recurrent postanesthesia care unit respiratory events, and the need for opioid analgesia.

Conclusion With adequate screening and vigilance in the preoperative period, risk stratification should be undertaken for known and suspected OSA patients, and care should be individualized. Practical algorithms based on current best evidence and expert opinion may be useful in the perioperative management.

Objectives of this continuing professional development (CPD) module:

Upon completion of this CPD module, the reader will be able to:

1. Evaluate a known obstructive sleep apnea patient preoperatively.

2. Evaluate a suspected obstructive sleep apnea patient preoperatively.

3. Minimize the risk posed by obstructive sleep apnea intraoperatively.

4. Determine the postoperative disposition of a known obstructive sleep apnea patient after general anesthesia.

5. Determine the postoperative disposition of a suspected obstructive sleep apnea patient after general anesthesia.

\section{Summary review}

Obstructive sleep apnea (OSA) is defined by repetitive partial or complete upper airway obstruction characterized 
by episodes of breathing cessation during sleep lasting ten or more seconds. The recurring airway obstruction causes repeated arousals and increased sympathetic output that culminates in daytime hypersomnolence, memory loss, and other psychological disturbances. It is the most prevalent of sleep disorders. ${ }^{1}$ General population estimates of OSA are in the range of one in four males and one in ten females. The diagnosis of OSA is suspected by determining symptoms of OSA and is confirmed by observing the number of apnea and/or hypopnea episodes per hour or the apnea-hypopnea index (AHI) on an overnight polysomnography. A significant proportion of OSA patients remain undiagnosed when they present for surgery. ${ }^{2}$ This is of concern to the perioperative physician, as OSA has been associated with increased perioperative risk and postoperative complications. ${ }^{3,4}$ It is also an independent risk factor for increased all-cause mortality in the general community. ${ }^{5,6}$

Notwithstanding these increased perioperative risks, clinical practices pertaining to the perioperative management of OSA surgical patients are inconsistent. In 2006, the publication of the American Society of Anesthesiologists (ASA) practice guidelines for the perioperative management of patients with $\mathrm{OSA}^{7}$ attempted to address this issue, but the guidelines indicated that the literature lacked sufficient evidence-based findings to enable clinicians to formulate strategies for the preoperative evaluation and postoperative management of OSA. ${ }^{8}$

The present continuing professional development (CPD) module is based on a review of the current literature on OSA and anesthesia, the opinion of several experts in this field, discussions held at the Canadian Anesthesiologists' Society Ambulatory Anesthesia Research and Education Committee meeting in 2009, and OSA protocols from several hospitals (Toronto, Ontario; Ottawa, Ontario; Kingston, Ontario; San Diego, California; Boston, Massachusetts; and Cleveland, Ohio). Our objective is to present practical principles and functional algorithms to assist the anesthesiologist in decision-making when faced with managing the OSA patient during the perioperative period.

In this CPD module, we will answer the following key questions and put forward recommendations: 1) How should a known or suspected OSA patient be evaluated preoperatively? 2) What can be done intraoperatively to minimize the risk posed by OSA? and 3) What should determine the postoperative disposition of a known or suspected OSA patient after general anesthesia? The recommendations presented are based on broad principles and are not intended to be a substitute for the clinical judgment of anesthesiologists where individual patient-specific factors may require alteration of these recommendations.

\section{Preoperative evaluation of the known OSA patient} (Fig. 1)

The diagnosis and severity of OSA should be confirmed in a patient with known OSA. This can be achieved through obtaining the patient's history and reviewing polysomnography results. The total number of complete cessations (apnea) and partial obstructions (hypopnea) of breathing occurring per hour of sleep, or AHI, is measured. These pauses in breathing, which are associated with decrease in oxygenation of the blood, should last for at least ten seconds. According to the Canadian Thoracic Society guidelines, the diagnosis of OSA is based on an $\mathrm{AHI} \geq 5$ on polysomnography, and either 1) daytime sleepiness not explained by other factors, or 2) at least two other symptoms of OSA (choking and/or gasping during sleep, recurrent awakenings from sleep, unrefreshing sleep, daytime fatigue, or impaired concentration). ${ }^{9}$

Cut-offs for AHI have often been used to describe the severity of OSA. The American Academy of Sleep Medicine defines mild OSA as AHI 5-15, moderate OSA as AHI 15-30, and severe OSA as AHI $>30 .{ }^{10}$ Long-standing OSA may have systemic complications, including hypoxemia, hypercarbia, polycythemia, and cor pulmonale. Pulse oximetry may be a simple screening tool in the preoperative clinic. In our opinion, an oxygen saturation value of $<94 \%$ on room air in the absence of other causes should be a red flag for severe long-standing OSA. The presence of comorbidities, such as uncontrolled hypertension, arrhythmias, cerebrovascular disease, heart failure, metabolic syndrome, and obesity should be determined. The use of positive airway pressure (PAP) devices (continuous PAP, bilevel PAP, autotitrating PAP) and the compliance to PAP therapy should be assessed for the subgroup of patients who have been prescribed with PAP therapy.

It may be necessary to refer some patients with known OSA to the sleep medicine physician for preoperative reassessment, especially patients who have been lost to sleep medicine follow-up, those who have had recent exacerbation of OSA symptoms, and those who have undergone OSA-related airway surgery or have been noncompliant with PAP therapy. Due consideration should be given for the re-initiation of preoperative PAP in the noncompliant OSA patient, although evidence of its efficacy is lacking in this preoperative context.

Patients with moderate and severe OSA who have been on PAP therapy should continue PAP therapy in the preoperative period. ${ }^{7}$ The intraoperative anesthesia team should be alerted in advance, and perioperative OSA precautions should be undertaken. Some of these measures would include anticipating possible difficult airways, the use of short-acting anesthetics agents, opioid-minimization, full reversal of neuromuscular blockade verified prior to 
Fig. 1 Preoperative evaluation of known or suspected obstructive sleep apnea patient in the anesthesia clinic.

$₫$ Positive airway pressure (PAP) therapy - including continuous PAP, bilevel PAP, or autotitrating PAP

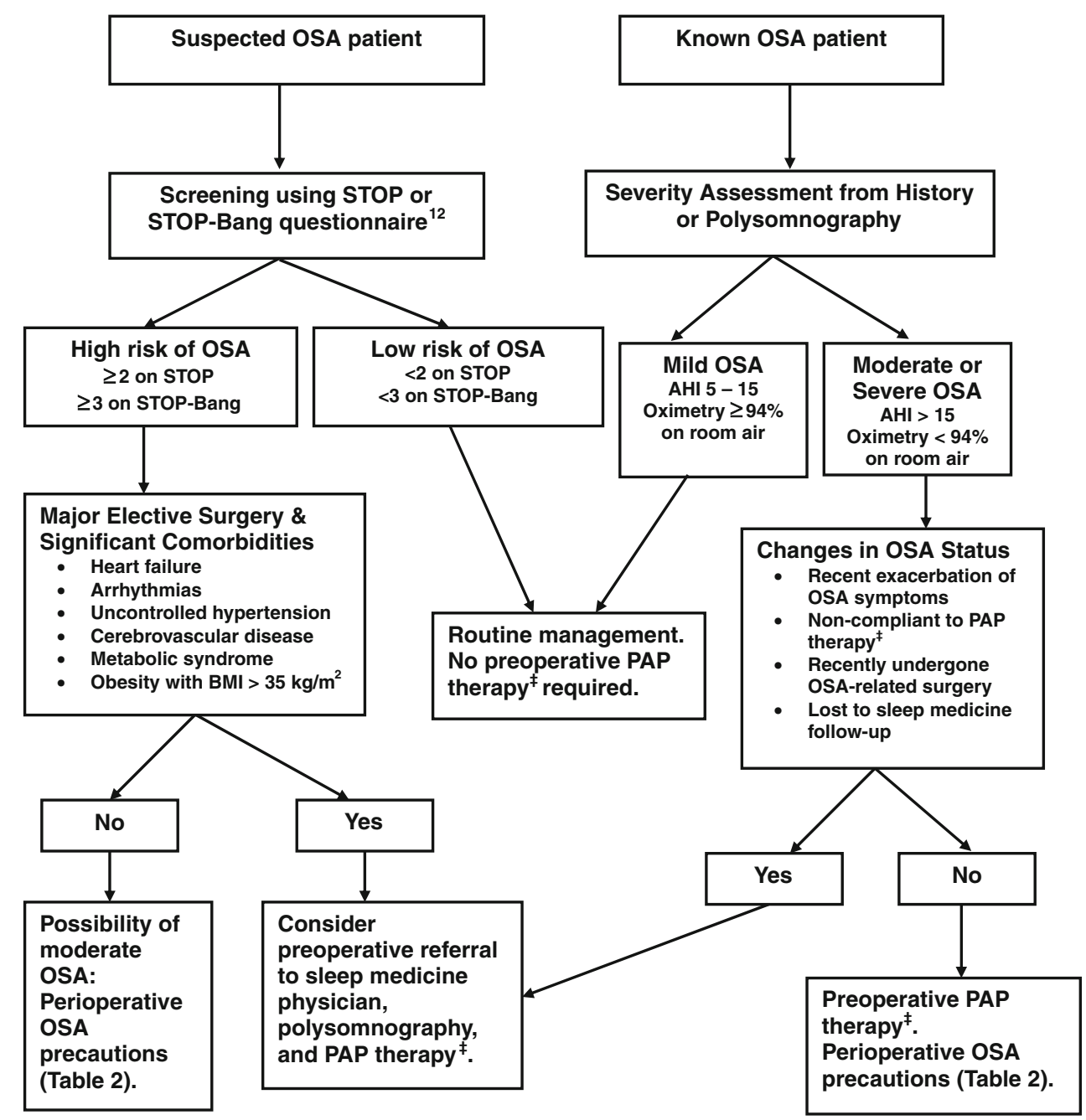

extubation, and extubation in a non-supine position. The respiratory depressant effects of sedatives, anesthetics, and analgesics may result in adverse postoperative respiratory events in the vulnerable OSA patient.

It is unclear from the current literature if mild OSA (AHI 5-15) would be a significant disease entity under anesthesia and in the perioperative period. Based on expert opinion, patients with mild OSA would not require preoperative PAP therapy. Mild OSA patients without respiratory events in the postanesthesia care unit (PACU) may be managed with routine perioperative care.

\section{Preoperative evaluation of the suspected OSA patient (Fig. 1)}

Loud snoring is a cry for help in OSA patients; while it is $100 \%$ sensitive, the specificity is low. Polysomnography is diagnostic for OSA, but costs and resource limitations make its routine use prohibitive. Therefore, practical screening tools for OSA sieve out the patients at higher risk of OSA and increase the pre-test (confirmatory polysomnography) probability.

Several questionnaire-based tools have been developed to screen for OSA, including the Berlin questionnaire ${ }^{11}$ and the ASA checklist. ${ }^{7}$ More recently, a concise clinical screening tool was developed for anesthesiologists - the STOP and the STOP-Bang questionnaires (Table 1). ${ }^{12} \mathrm{~A}$ comparative study validating the four questionnaires in preoperative surgical patients showed that there was no significant difference in predictive parameters for OSA between the different screening tools. ${ }^{13}$ More recently, in a meta-analysis of clinical screening tools for OSA, the STOP-Bang was identified as being easy to use and having a favourable diagnostic odds ratio, making it more suitable for predicting severe OSA in the preoperative setting. ${ }^{14}$ The sensitivity of the STOP questionnaire with AHI $>15$ and $>30$ as cut-offs was $74 \%$ and $80 \%$, respectively, and the specificity was $53 \%$ and $49 \%$, respectively. ${ }^{12}$ The STOP-Bang questionnaire has a sensitivity of $93 \%$ and $100 \%$ at AHI cut-offs of $>15$ and $>30$, respectively, with the specificity of $43 \%$ and $37 \%$, respectively. ${ }^{12}$ 
Table 1 Obstructive Sleep Apnea (OSA) Screening Tools

\section{STOP questionnaire}

1. Snoring: Do you snore loudly (loud enough to be heard through closed doors)?

Yes

No

2. Tired: Do you often feel $t$ ired, fatigued, or sleepy during daytime? Yes No

3.Observed: Has anyone observed you stop breathing during your sleep?

Yes No

4. Blood pressure: Do you have or are you being treated for high blood pressure?

Yes

No

High risk of OSA: Yes to 2 or more questions

Low risk of OSA: Yes to less than 2 questions

\section{STOP-Bang scoring model}

1. Snoring: Do you snore loudly (loud enough to be heard through closed doors)?

Yes No

2. Tired: Do you often feel $\boldsymbol{t}$ ired, fatigued, or sleepy during daytime? Yes No

3. Observed: Has anyone observed you stop breathing during your sleep?

Yes

No

4. Blood pressure: Do you have or are you being treated for high blood pressure?

Yes No

5. BMI: $\boldsymbol{B}$ MI more than $35 \mathrm{~kg} \bullet \mathrm{m}^{-2}$ ?

Yes

No

6. Age: $\boldsymbol{A}$ ge over 50 years old?

Yes

No

7. Neck circumference: $N$ eck circumference greater than $40 \mathrm{~cm}$ ?

Yes No

8. Gender: Male?

Yes No

High risk of OSA: Yes to 3 or more questions

Low risk of OSA: Yes to less than 3 questions

Adapted with permission from Chung $F$, Yegneswaran B, Liao P, et al. STOP Questionnaire: a tool to screen patients for obstructive sleep apnea. Anesthesiology 2008; 108: 812-21

In the authors' opinion, the STOP and the STOP-Bang questionnaires may be useful screening tools for the anesthesiologist. Ultimately, the decision as to which screening tool is most suitable lies with the clinicians and their institutional experience. A patient is at high risk of OSA if $\geq$ two items score positive on the STOP questionnaire, or $\geq$ three items score positive on the STOPBang questionnaire. ${ }^{12}$ If the high-risk patient is presenting for major elective surgery and has significant comorbidities suggestive of long-standing severe OSA, the anesthesiologist should consider a preoperative referral to the sleep physician and a recommendation for a polysomnography or a multichannel home sleep test if resources permit. These comorbidities include uncontrolled hypertension, heart failure, arrhythmias, cerebrovascular disease, morbid obesity, and metabolic syndrome.

A timely and early consult would allow the sleep physician adequate time to prepare a perioperative management plan, which may include PAP treatment. ${ }^{7}$ Major elective surgery may have to be deferred in patients with a high clinical suspicion of severe OSA with systemic complications. It should be noted that the specificity of the STOP and STOP-Bang questionnaires, the ASA checklist, and the Berlin questionnaire is in the $37-53 \%$ range for severe OSA. ${ }^{15}$ Therefore, a fairly high false-positive rate exists. Ultimately, the decision for further preoperative sleep study testing should depend on the clinical judgment and expertise of the attending physician, taking into account the patient-specific and logistical considerations in their totality.

On the other hand, there may be patients who are at high risk according to the OSA screening questionnaires, but who otherwise are without significant comorbidities and are not scheduled to undergo major surgery. Some of these patients may have had uneventful anesthetics in the past. These atrisk patients may represent false positives on screening or represent patients with less severe OSA (AHI < 15). A positive screening test would raise awareness and alert the anesthesiologist to undertake perioperative precautions for possible OSA. It can be assumed that these patients possibly have moderate to severe OSA, and if subsequent intraoperative (e.g., difficult airway) ${ }^{16}$ or postoperative events (PACU recurrent respiratory events) ${ }^{17}$ suggest a higher probability of OSA, a polysomnography and a sleep physician referral after the surgery may be indicated.

Due to the high sensitivity and negative predictive value of the OSA screening tools, the incidence of false negatives should be low. Therefore patients who are at low risk of OSA ( $<2$ on STOP or $<3$ on STOP-Bang) are unlikely to have OSA. These patients may be managed with routine perioperative care.

\section{Intraoperative management of the known or suspected OSA patient}

Perioperative precautions can be thought of as measures that may be undertaken to minimize adverse outcomes in OSA patients. These perioperative precautions are outlined in this section and summarized in Table 2.

Difficulty with tracheal intubation occurs eight times more often in OSA patients than in non-OSA patients. ${ }^{18}$ Adequate airway preparation should be made according to ASA difficult airway management guidelines. ${ }^{19}$ Patient should be adequately preoxygenated before induction of 
Table 2 Intraoperative anesthetic management of the patient with obstructive sleep apnea (OSA precautions)

\begin{tabular}{|c|c|}
\hline Anesthetic concern & Principles of management \\
\hline Sedative premedication & $\begin{array}{l}\text { Avoid sedating premedication. } \\
\text { Alpha- } 2 \text { adrenergic agonist (clonidine, dexmedetomidine) }{ }^{24} \text { may reduce } \\
\text { intraoperative anesthetic requirements and have an opioid-sparing effect. }\end{array}$ \\
\hline Possible difficult airway ${ }^{18}$ & $\begin{array}{l}\text { Ramp from scapula to head if patient is obese. } \\
\text { Adequate preoxygenation. } \\
\text { ASA Difficult Airway Algorithm. }{ }^{19}\end{array}$ \\
\hline Gastroesophageal reflux disease ${ }^{20}$ & $\begin{array}{l}\text { Consider proton pump inhibitors, antacids, rapid sequence } \\
\text { induction with cricoid pressure. }\end{array}$ \\
\hline Opioid-related respiratory depression ${ }^{8}$ & $\begin{array}{l}\text { Minimize use of opioids for analgesia. } \\
\text { Use of short-acting agents (remifentanil). } \\
\text { Regional and multimodal analgesia (NSAIDs, acetaminophen, tramadol, } \\
\text { ketamine, gabapentin, pregabalin, dexmedetomidine, dexamethasone). }\end{array}$ \\
\hline $\begin{array}{l}\text { Carry-over sedation effects from longer-acting intravenous } \\
\text { sedatives and inhaled anesthetic agents }\end{array}$ & $\begin{array}{l}\text { Use of propofol / remifentanil for maintenance of anesthesia } .^{8} \\
\text { Use of insoluble potent anesthetic agents (desflurane) } .^{8} \\
\text { Use of regional blocks as a sole anesthetic technique. }{ }^{7}\end{array}$ \\
\hline Excessive sedation in monitored anesthetic care ${ }^{7}$ & Use of intraoperative capnography for monitoring of respiration. ${ }^{7}$ \\
\hline Post-extubation airway obstruction & $\begin{array}{l}\text { Verification of full reversal of neuromuscular blockade. }{ }^{7} \\
\text { Ensure patient fully conscious and cooperative prior to extubation. }{ }^{7} \\
\text { Non-supine posture for extubation and recovery. }{ }^{7} \\
\text { Resume use of positive airway pressure device. }{ }^{7}\end{array}$ \\
\hline
\end{tabular}

ASA = American Society of Anesthesiologists; NSAIDs = non-steroidal anti-inflammatory drugs

general anesthesia. Facilitating laryngoscopy in obese OSA patients may require building a ramp under the patient from the scapula to the head to allow alignment of the ear and the sternal notch. A variety of airway adjuncts, such as a videolaryngoscope, and skilled anesthesiology assistance should be made available in advance. Gastroesophageal reflux disease is more prevalent in OSA patients due to hypotonia of the lower esophageal sphincter. ${ }^{20}$ To reduce the risk of aspiration, the use of proton pump inhibitors, antacids, rapid sequence induction, and cricoid pressure may be considered. Notably, cricoid pressure may make tracheal intubation and mask ventilation more difficult, ${ }^{21}$ compounding the problem of difficult airways in OSA patients.

The use of regional blocks (neuroaxial or peripheral nerve blocks) as a sole anesthetic may be beneficial to the OSA patient, as it circumvents the issue of upper airway patency in the perioperative period. Therefore, local and regional techniques may be preferred to general anesthesia. ${ }^{7}$ The postoperative use of nerve block catheters or epidural catheters with local anesthetics reduces the opioid requirement and this may be advantageous.

Patients with OSA are sensitive to the respiratory depressant effects of anesthetic agents, including sedatives, opioids, and inhaled anesthetics. This is because of the propensity of airway collapse, sleep deprivation, and blunting of the physiological response to hypercarbia and hypoxia. The use of short-acting agents (propofol, remifentanil, desflurane) is recommended and, correspondingly, the avoidance or minimization of the use of longer-acting anesthetic drugs. Tracheal extubation should be performed only after the OSA patient is fully conscious, airway patency confirmed, and full reversal of neuromuscular blockade verified. A non-supine position (semiupright or lateral) is preferred for postoperative recovery. ${ }^{7}$

A multimodal approach for analgesia is advocated (nonsteroidal anti-inflammatory drugs, COX-2 inhibitors, acetaminophen, tramadol, ketamine, pregabalin, gabapentin, and/or dexamethasone) for their opioid-sparing effect. This approach alleviates the opioid-related respiratory depressant effect in vulnerable OSA patients. Postoperative oxygen desaturations were 12-14 times more likely to occur in OSA patients receiving postoperative oral or parenteral opioids $v s$ non-opioid analgesic agents. ${ }^{22}$

Patients undergoing surgical procedures under monitored anesthetic care or regional anesthesia with sedation should have intraoperative capnography available to monitor for ventilation. If deep sedation is required, a secure airway is preferable to an unprotected airway. ${ }^{7}$

\section{Postoperative disposition of the known or suspected OSA patient after general anesthesia}

Patient-specific, anesthesia-specific, analgesia-specific, and surgery-specific factors determine the requirements for 
Fig. 2 Postoperative management of the known or suspected obstructive sleep apnea patient after general anesthesia "Recurrent postanesthesia care unit (PACU) respiratory event - any event occurring more than once in each $30-\mathrm{min}$ evaluation period (not necessary to be the same event). ${ }^{17}$ †Positive airway pressure (PAP) therapy including continuous PAP, bilevel PAP, or auto-titrating PAP. †Monitored bed environment with continuous oximetry and the possibility of early nursing intervention (e.g., intensive care unit, step-down unit, or remote pulse oximetry with telemetry in surgical ward). Pain-sedation mismatch $=$ simultaneous occurrence of high pain scores and high sedation levels

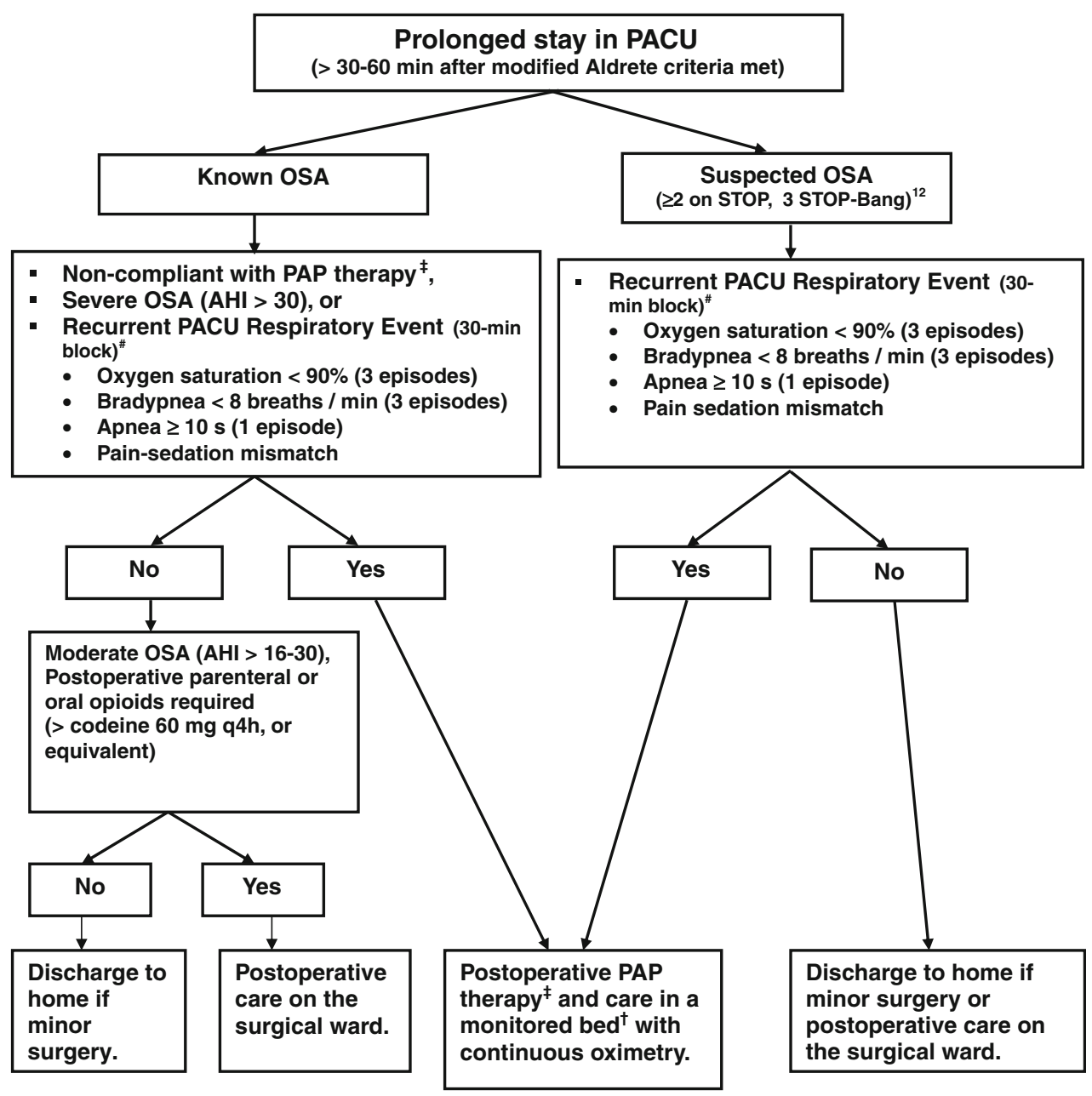

postoperative monitoring in OSA patients. For example, the patient with a high AHI undergoing extensive airway surgery would likely require close and continuous postoperative monitoring; in contrast, routine postoperative care might be sufficient in the suspected OSA patient undergoing minor elective surgery.

The 2006 ASA guidelines were directed by expert consensus in the absence of good clinical evidence at that time. The ASA task force has recommended that OSA patient disposition be based on risk factors and a weighted scoring system. ${ }^{7}$ The patient's risk is determined broadly by the following categories: 1) the severity and treatment of OSA, 2) the type of surgery and anesthesia, and 3) the need for postoperative opioids. The total score is a summation of category 1 , and the greater of the scores in category 2 or 3 . The total risk score will be a guide for the anticipated requirement for postoperative monitoring.

In reality, the final decision as to whether the patient requires closer postoperative monitoring is based on the judgement and discretion of the attending anesthesiologist. Modelled on similar principles as the ASA guidelines and recent evidence, we propose a simpler algorithm to guide the anesthesiologist in decision-making for the postoperative disposition of the OSA patient (Fig. 2).

The observation of recurrent PACU respiratory events can be used as a reliable second phase indicator to determine whether the known or suspected OSA patient requires continuous postoperative monitoring. A PACU respiratory event occurs in one 30-min time block when a patient has apnea for $\geq$ ten seconds (one episode needed for yes), bradypnea of $<8$ breaths $\cdot \mathrm{min}^{-1}$ (three episodes needed for yes), pain-sedation mismatch, or desaturations to $<90 \%$ (three episodes needed for yes). Pain-sedation mismatch is characterized by high pain scores and high sedation levels observed simultaneously. Recurrent PACU respiratory events occur when any one of the PACU respiratory events occurs in two separate 30-min time blocks (not necessary to be the same event). ${ }^{17}$

Patients who are at high risk of OSA on the screening questionnaires and have recurrent PACU respiratory events are more likely to have postoperative respiratory complications. ${ }^{17}$ It may be prudent to monitor these patients 
continuously postoperatively with oximetry in an area where early medical intervention can occur. The monitoring can occur in the step-down unit, on the surgical ward near the nursing station, or with remote pulse oximetry with telemetry (Fig. 2). These patients may also require commencement of postoperative PAP therapy.

Known OSA patients who have been non-compliant with PAP therapy or have severe OSA may have to be fitted with postoperative PAP therapy and cared for in a monitored environment with continuous oximetry, particularly if there has been a recurrent PACU respiratory event (Fig. 2).

Moderate OSA patients requiring postoperative parenteral opioids or higher dose oral opioids ( $>$ codeine $60 \mathrm{mg}$ every $4 \mathrm{hr}$ or equivalent) and without recurrent PACU respiratory events can be managed postoperatively on the surgical ward with periodic oximetry monitoring (Fig. 2). It may also be expedient to place patients requiring postoperative parenteral opioids on supplemental oxygen. ${ }^{23}$

Multimodal analgesic techniques should be utilized to minimize the postoperative administration of opioids. These would include peripheral nerve block catheters or neuroaxial catheters dispensing local anesthetic agents (without opioids) and opioid-sparing analgesic agents, such as, non-steroidal anti-inflammatory drugs, COX-2 inhibitors, ketamine, acetaminophen, pregabalin, gabapentin, tramadol, dexmedetomidine, ${ }^{24}$ and dexamethasone. ${ }^{25}$ Known OSA patients previously on PAP therapy should be encouraged to be compliant with PAP therapy postoperatively, and PAP therapy should be ordered in the postoperative period. Notably, normalization of sleep architecture and AHI occurs only on the seventh postoperative night. ${ }^{26}$ Further research on the postoperative management of OSA patients is essential.

Disagreement exists as to whether OSA patients should be discharged for home after surgery. The ASA guidelines highlighted that superficial surgeries or minor orthopedic surgery using local or regional techniques and lithotripsy may be performed on an ambulatory basis. ${ }^{7}$ In our opinion, mild OSA patients (AHI 5-15), who have undergone minor surgery without recurrent PACU respiratory events and who do not require high doses of oral opioids for analgesia, may be discharged home at the discretion of the attending physicians (Fig. 2). Ambulatory surgical centres managing OSA patients should have transfer agreements to inpatient facilities and should be equipped to manage contingencies associated with OSA.

\section{Conclusions}

In the perioperative setting, the dangerous combination of high prevalence and underdiagnosis makes OSA a formidable foe. It is known that OSA is associated with increased patient complications and postoperative morbidity. Detailed screening and vigilance in the preoperative period with risk stratification of known and suspected OSA patients allow individualized and tailored patient care. Practical algorithms based on current best evidence and expert opinion may guide anesthesiologists in the perioperative management of these vulnerable patients.

\section{Clinical case scenario}

Mr. Smith is a 60-yr-old Caucasian gentleman who presents with a history of right knee pain and deformity. He also has difficulty walking long distances. A consultation with the orthopedic surgeon and knee $x$-rays confirmed the diagnosis of right knee osteoarthritis. He is scheduled for a unilateral right knee arthroplasty and comes to the anesthesia clinic for a preoperative assessment. Twenty years ago, Mr. Smith underwent multiple operations to the lumbar spine for a "bad back", and he still has residual sciatica in the left leg. He has requested not to have spinal anesthesia.

During the preoperative evaluation, you gather a history of multiple comorbidities. These include previous stroke, hyperlipidemia, and poorly controlled hypertension. Mr. Smith's usual medications are amlodipine and aspirin. Mrs. Smith is also with you in the consultation room and she adds that Mr. Smith snores very loudly and stops breathing when he sleeps. Due to the loud snoring, they sleep in separate rooms. Even then, the snoring is still audible. Mr. Smith is also constantly tired during the day. No previous sleep studies were performed.

On examination, Mr. Smith is $1.70 \mathrm{~m}$ tall and weighs $140 \mathrm{~kg}$. His resting blood pressure is $180 / 95 \mathrm{mmHg}$ and his heart rate is $80 \bullet \mathrm{min}^{-1}$. Oxygen saturation value via pulse oximetry is $92 \%$ on room air. His neck circumference is $46 \mathrm{~cm}$. The scar from the previous spine procedures is noted. The rest of the examination is unremarkable.

\section{Instructions for completing the continuing professional development (CPD) module}

(1) Read the current article and the references indicated in bold.

(2) Go to: https://www.cpass2.umontreal.ca/selfassessment program/, and select the current module (Management of sleep apnea in adults - functional algorithms for the perioperative period).

(3) Answer the multiple choice questions regarding the case scenario. 
(4) Once you have entered all of your answers, you will have access to experts' explanations for all the possible choices.

(5) Participants may claim up to four hours of CPD, for a total of eight credits under Section 3 of the CPD program of the Royal College of Physicians and Surgeons of Canada.

\section{La prise en charge de l'apnée du sommeil chez l'adulte: algorithmes fonctionnels en période périopératoire}

\begin{abstract}
Résumé
Objectif L'apnée obstructive du sommeil (AOS) est définie par une obstruction répétitive partielle ou complète des voies aériennes supérieures caractérisée par des épisodes d'interruption de la respiration pendant le sommeil. Il s'agit du trouble du sommeil le plus répandu, et on l'observe chez environ un homme sur quatre et une femme sur dix. Nous avons passé en revue la littérature actuelle portant sur le sujet, colligé les opinions d'experts et résumé les protocoles de plusieurs institutions afin de présenter des principes pratiques et des algorithmes fonctionnels qui pourront aider l'anesthésiologiste lors de la prise en charge périopératoire d'une AOS connue ou soupçonnée.
\end{abstract}

Constatations principales Les patients souffrant d'AOS pourraient manifester davantage de complications respiratoires postopératoires, des arythmies soutenues, de l'hypertension ainsi que d'autres événements cardiovasculaires. La polysomnographie est l'étalon or du diagnostic d'AOS. Le questionnaire de Berlin et la liste de contrôle de l'AOS de l'American Society of Anesthesiologists sont des outils de dépistage utiles, et les questionnaires STOP et STOP-Bang sont faciles à appliquer chez l'adulte. On peut référer à un spécialiste les patients devant subir une chirurgie non urgente majeure et qui présentent un risque élevé d'AOS accompagné d'importantes comorbidités, pour qu'ils subissent une polysomnographie. Des précautions périopératoires devraient être prises pour les patients dont on sait ou soupçonne qu'ils présentent un risque élevé d'AOS: par exemple, en prévoyant des voies aériennes potentiellement difficiles d'accès, en utilisant des agents anesthésiques à courte action, en évitant les opiö̈es et en les extubant dans une position autre que dorsale. L'orientation postopératoire d'un patient souffrant d'AOS devrait se fonder sur la gravité du trouble du sommeil, les complications respiratoires récurrentes en salle de réveil, et le besoin ou non d'une analgésie opioïle.

Conclusion En effectuant un dépistage approprié et en exerçant de la vigilance en période préopératoire, la stratification des risques devrait être entreprise pour les patients souffrant d'AOS connue ou soupçonnée. En outre, les soins doivent être personnalisés. Des algorithmes pratiques basés sur les meilleures données probantes actuelles et les opinions d'experts pourraient s'avérer utiles lors de la prise en charge périopératoire.

\section{Objectifs de ce module de développement professionnel continu (DPC):}

À la fin de ce module de DPC, le lecteur sera capable de:

1. Évaluer un patient souffrant d'apnée obstructive du sommeil connue lors de la visite préopératoire.

2. Évaluer un patient chez qui on soupçonne une apnée obstructive du sommeil lors de la visite préopératoire.

3. Minimiser les risques associés à l'apnée obstructive du sommeil pendant l'opération.

4. Après une anesthésie générale, déterminer l'orientation postopératoire des patients souffrant d'apnée du sommeil connue.

5. Après une anesthésie générale, déterminer l'orientation postopératoire des patients chez qui on soupçonne une apnée du sommeil.

\section{Synthèse}

L'apnée obstructive du sommeil (AOS) est définie par une obstruction répétitive partielle ou complète des voies aériennes supérieures, laquelle se caractérise par des épisodes d'interruption de la respiration pendant le sommeil d'une durée de dix secondes ou plus. L'obstruction récurrente des voies aériennes cause des réveils répétés et un débit sympathique accru qui culmine en une hypersomnolence de jour, des pertes de mémoire et d'autres troubles psychologiques. Il s'agit du trouble du sommeil le plus répandu. ${ }^{1}$ On estime que l'AOS touche, dans la population générale, un homme sur quatre et une femme sur dix. Un diagnostic d'AOS est soupçonné en présence de symptômes d'AOS, puis confirmé en observant le nombre d'épisodes d'apnée et/ou d'hypopnée par heure, ou index apnée hypopnée (IAH), à l'aide d'une polysomnographie réalisée au cours d'une nuit. Une proportion significative de patients souffrant d'AOS ne sont pas diagnostiqués comme tels lorsqu'ils se présentent 
pour une chirurgie. ${ }^{2}$ Ce manque de diagnostic est préoccupant pour les médecins périopératoires, étant donné que l'AOS a été associée à un risque périopératoire accru et des complications postopératoires. ${ }^{3,4}$ L'AOS est également un facteur de risque indépendant de mortalité accrue, toutes causes confondues, dans la population en général. ${ }^{5,6}$

Nonobstant ces risques périopératoires accrus, les pratiques cliniques en ce qui touche à la prise en charge périopératoire de patients souffrant d'AOS sont très inégales. En 2006, la publication des directives de pratique de l'American Society of Anesthesiologists (ASA) pour la prise en charge périopératoire des patients souffrant $\mathrm{d}^{\prime} \mathrm{AOS}^{7}$ a tenté de pallier ce problème. Cependant, ces directives indiquaient que la littérature manquait de données probantes suffisantes pour permettre aux cliniciens de formuler des stratégies pour l'évaluation préopératoire et la prise en charge postopératoire de l'AOS. ${ }^{8}$

Ce module de développement professionnel continu (DPC) s'appuie sur une revue de la littérature actuelle portant sur l'AOS et l'anesthésie, l'opinion de plusieurs experts dans le domaine, les discussions menées lors de la réunion du Comité de formation et de recherches en anesthésie ambulatoire de la Société canadienne des anesthésiologistes en 2009, ainsi que sur divers protocoles d'AOS provenant de plusieurs hôpitaux (Toronto, Ontario; Ottawa, Ontario; Kingston, Ontario; San Diego, Californie; Boston, Massachusetts; et Cleveland, Ohio). L'objectif de ce module est de présenter des principes pratiques et des algorithmes fonctionnels qui guideront l'anesthésiologiste lors de la prise de décision quant à la prise en charge d'un patient souffrant d'AOS en période périopératoire.

Dans ce module de DPC, nous répondrons aux questions essentielles suivantes et proposerons des recommandations: 1) Comment évaluer un patient souffrant d'AOS connue ou soupçonnée avant l'opération?

2) Que peut-on faire pendant l'opération pour minimiser les risques que pose l'AOS? et 3) Après une anesthésie générale, qu'est-ce qui devrait déterminer l'orientation postopératoire d'un patient souffrant d'une AOS connue ou soupçonnée? Les recommandations présentées se fondent sur de vastes principes et ne sont pas destinées à remplacer le jugement clinique de l'anesthésiologiste lorsque des facteurs spécifiques à un patient donné pourraient justifier des modifications à ces recommandations.

\section{Évaluation préopératoire du patient souffrant d'AOS connue (fig. 1)}

Le diagnostic et la gravité de l'AOS devraient être confirmés chez le patient souffrant d'AOS connue. Pour ce faire, on peut consulter les antécédents du patient et passer en revue ses résultats de polysomnographie. On mesure l'IAH, soit le nombre total d'interruptions complètes (apnée) et d'obstructions partielles (hypopnées) de la respiration par heure de sommeil. Ces pauses dans la respiration, qui sont associées à une réduction de l'oxygénation du sang, doivent durer au moins dix secondes. Selon les directives de la Société canadienne de thoracologie, le diagnostic d'AOS est posé lorsque l'IAH $\geq 5$ sur le polysomnographe, et qu'il est accompagné de 1) une somnolence diurne inexpliquée par d'autres facteurs, ou 2) au moins deux autres symptômes d'AOS (suffocation et/ou respiration haletante pendant le sommeil, réveils récurrents, sommeil non réparateur, fatigue diurne, ou concentration réduite). ${ }^{9}$

Des seuils de l'IAH ont été régulièrement utilisés pour décrire la gravité de l'AOS. L'American Academy of Sleep Medicine définit une AOS légère comme un IAH entre 5 et 15 , une AOS modérée comme ayant des valeurs entre 15 et 30 sur l'IAH, et une AOS grave avec toute valeur d'IAH $>30 .{ }^{10}$ Une AOS de longue date peut entrainer des complications systémiques, notamment l'hypoxémie, l'hypercarbie, la polyglobulie et le cœur pulmonaire. L'oxymétrie du pouls peut constituer un outil facile de dépistage en clinique préopératoire. Selon nous, toute valeur de saturation d'oxygène $<94 \%$ à l'air ambiant, en l'absence d'autres causes, devrait constituer un avertissement d'AOS grave de longue date. La présence de comorbidités, telles qu'une hypertension non contrôlée, des arythmies, une maladie vasculaire cérébrale, une insuffisance cardiaque, un syndrome métabolique et de l'obésité, devrait être déterminée. L'utilisation de dispositifs de ventilation en pression positive (PAP) (ventilation en pression positive continue, à deux niveaux, auto-titrée) et l'observance du traitement de PAP devrait être évaluée chez les patients auxquels on a prescrit un traitement de PAP.

Il pourrait s'avérer nécessaire de référer certains patients souffrant d'AOS connue au médecin responsable de la médecine du sommeil pour une réévaluation préopératoire, particulièrement dans le cas de patients pour lesquels le suivi n'a pas été fait en médecine du sommeil, ceux qui ont récemment manifesté une exacerbation des symptômes d'AOS, et ceux qui ont subi une chirurgie des voies aériennes liée à leur AOS ou n'ont pas été fidèles au traitement de PAP. Il importe de bien réfléchir avant de relancer un traitement préopératoire en PAP chez le patient souffrant d'AOS ne respectant pas le traitement, bien que nous ne disposions d'aucune donnée concernant son efficacité dans le contexte préopératoire.

Les patients souffrant d'AOS modérée à grave qui ont suivi un traitement de PAP devraient le maintenir pendant la période préopératoire. ${ }^{7}$ L'équipe d'anesthésie peropératoire doit être prévenue, et des précautions périopératoires d'AOS prises. Parmi les mesures à prendre, 
Fig. 1 Évaluation préopératoire d'un patient souffrant d'apnée obstructive du sommeil connue ou soupçonnée lors de la visite préopératoire. $\$$ Traitement de ventilation à pression positive (PAP) - y compris PAP continue, à deux niveaux, auto-titrée

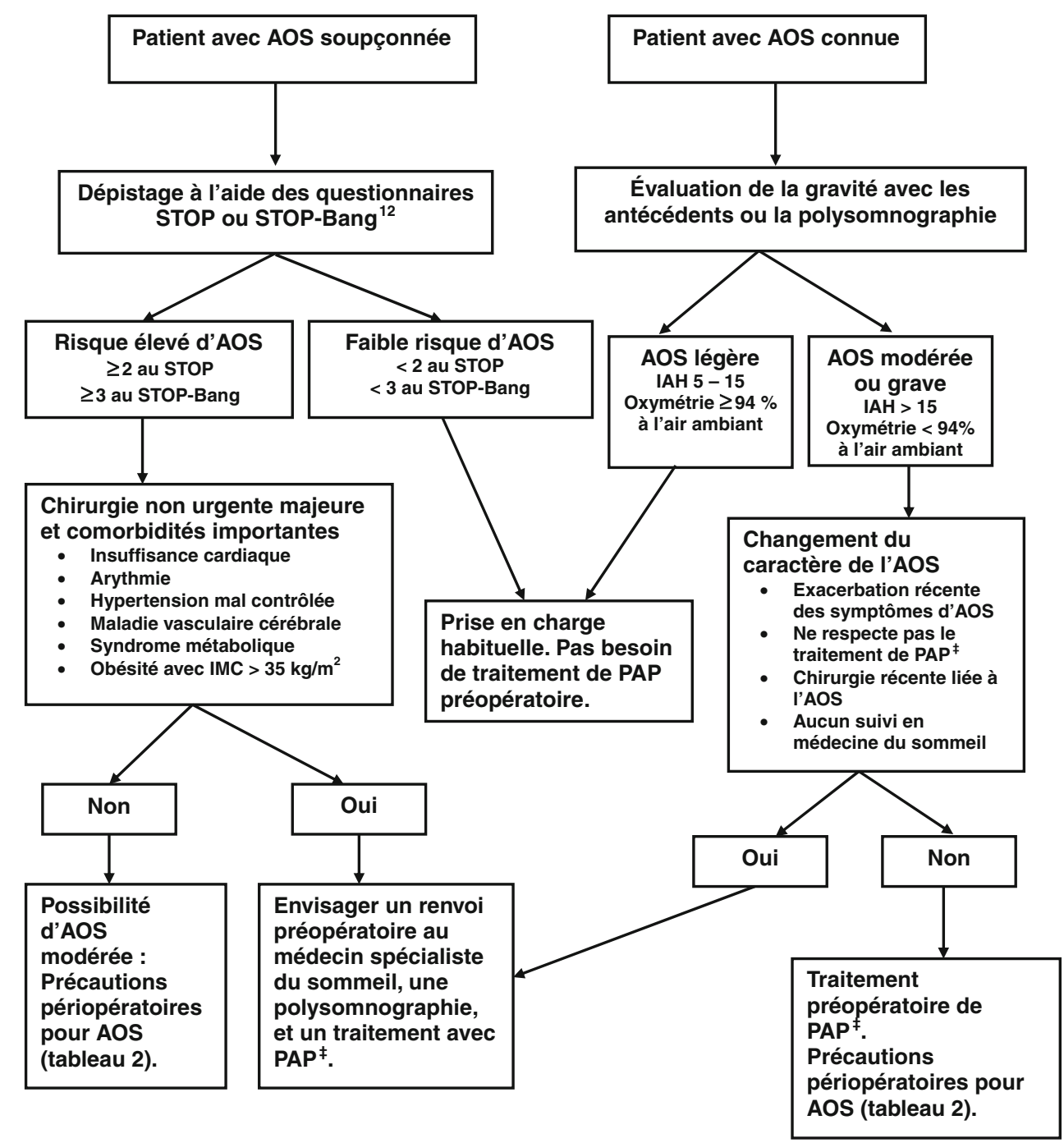

citons la prévision de voies aériennes potentiellement difficiles, l'utilisation d'agents anesthésiques à courte action, la minimisation des opiö̈des, la neutralisation complète du bloc neuromusculaire et sa vérification avant l'extubation, et l'extubation dans une position autre que dorsale. Les effets dépresseurs sur le système respiratoire des sédatifs, des anesthésiques et des analgésiques pourraient provoquer des complications respiratoires postopératoires chez le patient vulnérable souffrant d'AOS.

Si l'on se fonde sur la littérature actuelle, il est difficile de savoir si une AOS légère (IAH 5-15) constitue une entité morbide importante sous anesthésie générale et en période périopératoire. Selon les opinions d'experts, les patients souffrant d'une AOS légère ne nécessiteraient pas de traitement de PAP. Les patients souffrant d'une AOS légère et sans complications respiratoires en salle de réveil peuvent être pris en charge à l'aide des soins périopératoires habituels.

\section{Évaluation préopératoire du patient chez qui} on soupçonne une AOS (fig. 1)

Des ronflements sonores constituent un appel à l'aide chez les patients souffrant d'AOS; toutefois, bien que sensible à $100 \%$, la spécificité est peu élevée. La polysomnographie est un excellent outil de dépistage de l'AOS, mais les coûts et les restrictions au niveau des ressources en font un outil hors de prix pour une utilisation de routine. Pour cette raison, des outils pratiques de dépistage de l'AOS permettent de cibler les patients présentant un risque élevé d'AOS et augmentent la probabilité du test préliminaire (polysomnographie de confirmation).

Plusieurs outils basés sur des questionnaires ont été mis au point pour dépister l'AOS, notamment le questionnaire de Berlin ${ }^{11}$ et la liste de contrôle de l'ASA. ${ }^{7}$ Plus récemment, un outil de dépistage clinique concis a été élaboré pour les anesthésiologistes: les questionnaires 
Tableau 1 Outils de dépistage de l'apnée obstructive du sommeil (AOS)

\section{Questionnaire STOP}

1. Ronflements (Snoring): Vos ronflements sont-ils bruyants (suffisamment pour être entendus à travers une porte fermée)?

Oui

$$
\text { Non }
$$

2. Fatigué (Tired): Vous sentez-vous souvent fatigué, épuisé ou somnolent pendant la journée?

Oui Non

3. Observé: Quelqu'un a-t-il déjà observé que vous arrêtiez de respirer en dormant?

Oui Non

4. Tension artérielle (Blood Pressure): Avez-vous ou êtes-vous traités pour une tension artérielle élevée?

Oui

Non

Risque élevé d'AOS: Oui à 2 questions ou plus

Risque faible d'AOS: Oui à moins de 2 questions

\section{Modèle de pointage STOP-Bang}

1. Ronflements (Snoring): Vos ronflements sont-ils bruyants (suffisamment pour être entendus à travers une porte fermée)?

Oui

$$
\text { Non }
$$

2. Fatigué (Tired): Vous sentez-vous souvent fatigué, épuisé ou somnolent pendant la journée?

Oui

Non

3. Observé: Quelqu'un a-t-il déjà observé que vous arrêtiez de respirer en dormant?

Oui

Non

4. Tension artérielle (Blood Pressure): Avez-vous été ou êtes-vous traité pour une tension artérielle élevée?

Oui

Non

5. IMC (BMI): IMC de plus de $35 \mathrm{~kg} \bullet \mathrm{m}^{-2}$ ?

Oui

Non

6. Âge: Âgé de plus de 50 ans?

Oui

Non

7. Circonférence du cou (Neck): Circonférence du cou de plus de $40 \mathrm{~cm}$ ?

Oui

Non

8. Sexe (Gender): Homme?

Oui

Non

Risque élevé d'AOS: Oui à 3 questions ou plus

Risque faible d'AOS: Oui à moins de 3 questions

Adapté avec la permission de Chung F, Yegneswaran B, Liao P, et al. STOP Questionnaire: a tool to screen patients for obstructive sleep apnea. Anesthesiology 2008; 108: 812-21

STOP et STOP-Bang (tableau 1). ${ }^{12}$ Une étude comparative validant les quatre questionnaires chez des patients devant subir une opération a démontré qu'il n'y avait pas de différence significative au niveau des paramètres de prédiction de l'AOS entre les différents outils de dépistage. ${ }^{13}$ Plus récemment, dans une méta-analyse examinant les outils cliniques de dépistage de l'AOS, il a été déterminé que le questionnaire STOP-Bang était facile à utiliser et disposait d'un rapport de cotes diagnostique favorable, ce qui en fait un outil mieux adapté pour prédire une AOS grave dans un contexte préopératoire. ${ }^{14} \mathrm{La}$ sensibilité du questionnaire STOP avec des valeurs d'IAH $>15$ et $>30$ comme seuils était de $74 \%$ et $80 \%$, respectivement, et la spécificité était de $53 \%$ et $49 \%$, respectivement. ${ }^{12}$ Le questionnaire STOP-Bang a une sensibilité de $93 \%$ et $100 \%$ à des seuils d'IAH de $>15$ et $>30$, respectivement, avec une spécificité de $43 \%$ et $37 \%$, respectivement. ${ }^{12}$

Selon nous, les questionnaires STOP et STOP-Bang peuvent constituer des outils de dépistage utiles à l'anesthésiologiste. En fin de compte, la décision de déterminer quel outil de dépistage est le plus adapté doit être prise par les cliniciens selon l'expérience de leur institution. Un patient présente un risque élevé d'AOS si $\geq$ deux éléments sont positifs dans le questionnaire STOP, ou $\geq$ trois éléments sont positifs dans le questionnaire STOP-Bang. ${ }^{12} \mathrm{Si}$ un patient à risque élevé se présente pour une chirurgie non urgente majeure et exhibe des comorbidités importantes suggérant une AOS grave et de longue durée, l'anesthésiologiste devrait envisager un renvoi préopératoire au médecin spécialiste du sommeil et une recommandation de polysomnographie ou de test de sommeil multicanal à réaliser à la maison, les ressources le permettant. Parmi les comorbidités, citons une hypertension non contrôlée, une insuffisance cardiaque, de l'arythmie, une maladie vasculaire cérébrale, une obésité morbide et un syndrome métabolique.

Une consultation en temps opportun pourrait donner au médecin spécialiste du sommeil suffisamment de temps pour élaborer un plan de prise en charge périopératoire qui pourrait comprendre un traitement de PAP. ${ }^{7}$ Il est possible que la chirurgie non urgente majeure doive être remise chez les patients pour lesquels il y a une suspicion élevée d'AOS grave accompagnée de complications systémiques. Il faut souligner que la spécificité des questionnaires STOP et STOP-Bang, de la liste de contrôle ASA et du questionnaire de Berlin se situe dans une marge allant de 37-53\% pour l'AOS grave. ${ }^{15}$ Ainsi, il y a un taux de faux positifs relativement élevé. Finalement, la décision de réaliser des tests supplémentaires sur le sommeil avant l'opération devrait s'appuyer sur le jugement clinique et l'expertise du médecin, en tenant compte de toutes les considérations, qu'elles soient logistiques et spécifiques au patient.

En revanche, certains patients pourraient présenter un risque élevé d'AOS selon les questionnaires de dépistage mais sans présenter de comorbidités significatives et sans devoir subir d'intervention chirurgicale majeure. Certains de ces patients pourraient avoir été anesthésiés sans incident par le passé. Ces patients à risque pourraient représenter des faux positifs lors du dépistage ou des patients souffrant d'AOS moins grave (IAH $<15$ ). Un test de dépistage positif devrait attirer l'attention et alerter 
l'anesthésiologiste afin qu'il prenne des précautions périopératoires dans le cas d'une AOS potentielle. On peut présumer que ces patients souffrent possiblement d'AOS modérée à grave, et si des complications peropératoires (par ex., voies aériennes difficiles) ou postopératoires (complications respiratoires récurrentes en salle de réveil) subséquentes suggèrent une probabilité plus élevée d'AOS, une polysomnographie et un renvoi au médecin spécialiste du sommeil après la chirurgie pourraient alors être indiqués.

En raison de la sensibilité et de la valeur prédictive négative élevées des outils de dépistage de l'AOS, l'incidence de faux négatifs devrait être faible. C'est pourquoi il est peu probable que les patients qui présentent un risque faible d'AOS $(<2$ au STOP ou $<3$ au STOP-Bang) souffrent d'AOS. Ces patients peuvent être pris en charge avec les soins périopératoires habituels.

\section{Prise en charge peropératoire du patient souffrant d'AOS connue ou soupçonnée}

Les précautions périopératoires peuvent être envisagées comme des mesures qui peuvent être prises pour minimiser les complications chez les patients souffrant d'AOS. Ces précautions périopératoires sont décrites dans cette section et résumées dans le tableau 2 .

Une intubation trachéale difficile survient huit fois plus souvent chez des patients souffrant d'AOS que chez des patients sans AOS. ${ }^{18}$ Une préparation adéquate pour la prise en charge des voies aériennes devrait être réalisée selon les directives de l'ASA. ${ }^{19}$ Le patient doit être bien pré-oxygéné avant l'induction de l'anesthésie générale. Pour faciliter la laryngoscopie chez les patients obèses souffrant d'AOS, il peut être utile de construire une rampe sous le patient allant de l'omoplate à la tête afin d'aligner l'oreille et l'échancrure sternale. Divers ajouts à la prise en charge des voies aériennes, comme un vidéolaryngoscope et une assistance compétente en anesthésiologie, devraient être disponibles à l'avance. Le reflux gastro-œsophagien est plus prévalent chez les patients souffrant d'AOS en raison de l'hypotonie du sphincter inférieur de l'œsophage. ${ }^{20}$ Pour réduire le risque d'inhalation, l'utilisation d'inhibiteurs de la pompe à protons, d'antiacides, d'une induction à séquence rapide et de pression cricoïdienne peuvent être envisagés. La pression cricoïdienne notamment pourrait rendre l'intubation trachéale et la ventilation au masque plus difficiles, ${ }^{21}$ compliquant le problème de voies aériennes difficiles chez des patients souffrant d'AOS.

L'utilisation de blocs régionaux (neuraxiaux ou périphériques) en tant que seul anesthésique pourrait être indiquée chez les patients souffrant d'AOS, étant donné que ces blocs évitent le problème de perméabilité des voies aériennes supérieures pendant la période périopératoire. Pour cette raison, des techniques d'anesthésie locale et régionale pourraient être préférées à une anesthésie générale. ${ }^{7}$ L'utilisation postopératoire de cathéters pour blocs nerveux

Tableau 2 Prise en charge de l'anesthésie chez le patient souffrant d'apnée obstructive du sommeil (précautions pour AOS)

\begin{tabular}{|c|c|}
\hline Préoccupation & Principes de prise en charge \\
\hline Prémédication & $\begin{array}{l}\text { Éviter les sédatifs en prémédication. } \\
\text { Les agonistes alpha- } 2 \text { adrénergiques (clonidine, dexmédétomidine) }{ }^{24} \text { pourraient réduire } \\
\text { les besoins anesthésiques peropératoires et éviter l'utilisation d'opioïdes. }\end{array}$ \\
\hline Voies aériennes possiblement difficiles & $\begin{array}{l}\text { Rampe depuis l'omoplate jusqu'à la tête si le patient est obèse. } \\
\text { Préoxygénation adaptée. } \\
\text { Algorithme des voies aériennes difficiles de l'ASA. }{ }^{19}\end{array}$ \\
\hline Reflux gastro-œsophagien pathologique & $\begin{array}{l}\text { Envisager des inhibiteurs de la pompe à protons, des antiacides, une induction en } \\
\text { séquence rapide avec pression cricoïdienne. }\end{array}$ \\
\hline Dépression respiratoire liée aux opioïdes ${ }^{8}$ & $\begin{array}{l}\text { Minimiser l'utilisation des opiö̈des pour l'analgésie. } \\
\text { Utilisation d'agents à courte action (rémifentanil). } \\
\text { Analgésie régionale et multimodale (AINS, acétaminophène, tramadol, kétamine, } \\
\text { gabapentine, prégabaline, dexmédétomidine, dexaméthasone). }\end{array}$ \\
\hline $\begin{array}{l}\text { Effets résiduels des sédatifs intraveineux et d'agents } \\
\text { anesthésiques inhalés à longue action }\end{array}$ & $\begin{array}{l}\text { Utilisation de propofol / rémifentanil pour le maintien de l'anesthésie. }{ }^{8} \\
\text { Utilisation d'agents anesthésiques insolubles puissants (desflurane). }{ }^{8} \\
\text { Utilisation de blocs régionaux en tant que technique d'anesthésie unique. }\end{array}$ \\
\hline Sédation excessive pendant la sédation consciente ${ }^{7}$ & Utilisation de capnographie peropératoire pour monitorer la respiration. ${ }^{7}$ \\
\hline Obstruction des voies aériennes après l'extubation & $\begin{array}{l}\text { Vérification de la neutralisation complète du bloc neuromusculaire. } \\
\text { S'assurer que le patient est complètement conscient et coopère avant de l'extuber. } \\
\text { Position non dorsale pour l'extubation et la récupération. } \\
\text { Reprendre l'utilisation de dispositifs de ventilation à pression positive. }\end{array}$ \\
\hline
\end{tabular}

ASA = American Society of Anesthesiologists; AINS = anti-inflammatoires non stéroïdiens 
ou de cathéters périduraux avec des anesthésiques locaux réduit le besoin en opioïdes, ce qui pourrait être un avantage.

Les patients souffrant d'AOS sont sensibles aux effets dépresseurs des agents anesthésiques sur la respiration, notamment les sédatifs, les opioïdes et les agents anesthésiques par inhalation. En effet, chez ces patients, les voies aériennes ont tendance à s'affaisser, il peut y avoir déficit de sommeil et les réponses physiologiques à l'hypercarbie et l'hypoxie sont émoussées. L'utilisation d'agents à courte action (propofol, rémifentanil, desflurane) est recommandée et, de même, l'abandon ou la minimisation d'agents anesthésiques à plus longue action. L'extubation trachéale devrait être entreprise seulement après que le patient souffrant d'AOS a regagné pleinement conscience, que la perméabilité des voies aériennes a été confirmée, et que la neutralisation complète du bloc neuromusculaire a été vérifiée. Une position autre que dorsale (semi-verticale ou latérale) doit être privilégiée pour la récupération postopératoire. ${ }^{7}$

Une approche multimodale de l'analgésie est recommandée (anti-inflammatoires non stérö̈diens, inhibiteurs de la COX-2, acétaminophène, tramadol, kétamine, prégabaline, gabapentine et/ou dexaméthasone) car ces agents permettent de diminuer les doses d'opioïdes. Cette approche atténue l'effet dépresseur des opioïdes sur le système respiratoire chez les patients vulnérables souffrant d'AOS. Après la chirurgie, les désaturations en oxygène étaient 12 à 14 fois plus probables si le patient souffrant d'AOS recevait des opioïdes oraux ou parentéraux plutôt que des agents analgésiques non opiö̈des. ${ }^{22}$

Dans le cas d'interventions chirurgicales sous sédation consciente ou sous anesthésie régionale avec sédation, la capnographie peropératoire devrait disponible pour monitorer la ventilation des patients. Si une sédation profonde est requise, des voies aériennes sécurisées sont préférables à des voies aériennes non protégées. ${ }^{7}$

\section{Orientation postopératoire après une anesthésie générale des patients souffrant d'AOS connue ou soupçonnée}

Des facteurs spécifiques au patient, à l'anesthésie, à l'analgésie et à la chirurgie déterminent les exigences en matière de monitorage postopératoire chez les patients souffrant d'AOS. Par exemple, un patient avec un IAH élevé subissant une chirurgie complexe des voies aériennes nécessitera probablement un monitorage attentif et continu; en revanche, des soins postopératoires habituels pourraient suffire pour un patient avec une AOS soupçonnée subissant une chirurgie non urgente mineure.

Les directives de l'ASA de 2006 ont été élaborées par un consensus d'experts, mais en l'absence de données probantes fiables à ce moment-là. Le groupe de travail de l'ASA recommande que l'orientation des patients souffrant d'AOS soit fondée sur les facteurs de risque et un système de pointage pondéré. ${ }^{7}$ Les risques encourus par le patient sont généralement déterminés par les catégories suivantes: 1) la gravité et le traitement de l'AOS; 2) le type de chirurgie et d'anesthésie; et 3 ) le besoin d'opioïdes après la chirurgie. Le score total est l'addition de la catégorie 1 et des scores les plus élevés dans les catégories 2 ou 3. Le score total de risque servira de guide pour anticiper les besoins de monitorage postopératoire.

En fait, la décision finale quant à la nécessité pour le patient d'une surveillance étroite se fonde sur le jugement et est à la discrétion de l'anesthésiologiste en charge. Sur la base de principes similaires à ceux des directives de l'ASA et de données probantes récentes, nous proposons un algorithme simplifié destiné à guider l'anesthésiologiste lors de la prise de décision concernant l'orientation postopératoire du patient souffrant d'AOS (fig. 2).

L'observation d'événements respiratoires récurrents en salle de réveil peut être utilisée comme indicateur fiable de deuxième phase pour déterminer si le patient souffrant d'AOS connue ou soupçonnée nécessite un monitorage postopératoire continu. Un événement respiratoire en salle de réveil survient dans un bloc de $30 \mathrm{~min}$ lorsque le patient est en apnée pour $\geq$ dix secondes (un épisode nécessaire pour un oui), une bradypnée à $<8$ respirations. $\min ^{-1}$ (trois épisodes nécessaires pour un oui), un déséquilibre douleur-sédation, ou des désaturations à $<90 \%$ (trois épisodes nécessaires pour un oui). Un déséquilibre entre douleur et sédation se caractérise par l'observation simultanée de scores de douleur élevés et de niveaux de sédation élevés. On parle d'événements respiratoires récurrents en salle de réveil quand au moins un événement respiratoire en salle de réveil survient dans deux blocs distincts de $30 \mathrm{~min}$ (ce n'est pas nécessairement la même complication). ${ }^{17}$

Il est plus probable que des patients qui présentent un risque élevé d'AOS sur la base des questionnaires de dépistage et manifestent des événements respiratoires récurrents en salle de réveil souffrent de complications respiratoires postopératoires. ${ }^{17}$ Il serait prudent de monitorer ces patients de façon continue après l'opération à l'aide de l'oxymétrie dans un endroit où une intervention médicale rapide peut avoir lieu. Le monitorage peut être réalisé à l'unité de soins intermédiaires, dans le service de chirurgie près du poste des soins infirmiers, ou à l'aide d'une oxymétrie du pouls à distance sous télésurveillance (fig. 2). Ces patients pourraient également nécessiter qu'une thérapie postopératoire de PAP soit amorcée.

Il peut être nécessaire d'installer une thérapie de PAP chez les patients avec une AOS connue et qui n'ont pas été fidèles à leur traitement de PAP ou qui souffrent d'une 
Fig. 2 Après une anesthésie générale, prise en charge postopératoire d'un patient souffrant d'apnée obstructive du sommeil connue ou soupçonnée. "Événement respiratoire récurrent en salle de réveil tout événement survenant plus d'une fois dans chaque période d'évaluation de 30 min (pas nécessairement le même événement). ${ }^{17}{ }^{*}$ Traitement de ventilation à pression positive (PAP) - y compris PAP continue, à deux niveaux, auto-titrée. 'Lit monitoré environnement disposant d'oxymétrie continue et permettant une intervention précoce de l'infirmière (par ex. unité des soins intensifs, ou oxymétrie du pouls à distance dans le service de chirurgie). Déséquilibre douleursédation $=$ survenue simultanée de scores de douleur élevés et de niveaux de sédation élevés

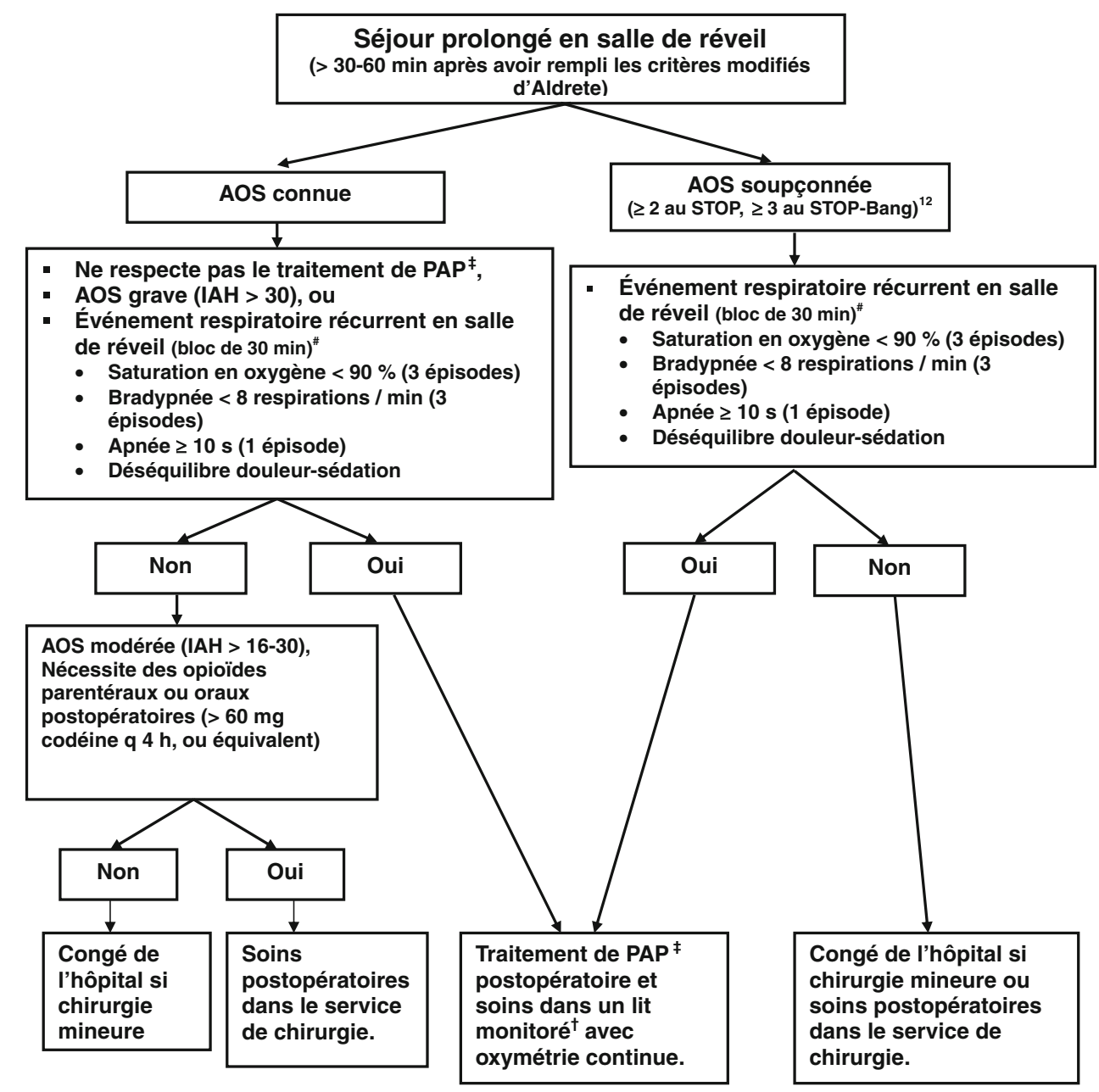

AOS grave; ces patients devraient être pris en charge dans un environnement surveillé à l'aide d'oxymétrie continue, particulièrement si un événement respiratoire récurrent en salle de réveil a eu lieu (fig. 2).

La prise en charge postopératoire des patients souffrant d'une AOS modérée nécessitant des opioïdes parentéraux ou une dose élevée d'opioïdes oraux ( $>60 \mathrm{mg}$ de codéine toutes les $4 \mathrm{~h}$ ou équivalent) mais n'ayant pas manifesté d'événement respiratoire récurrent en salle de réveil peut se faire dans le service de chirurgie avec un monitorage périodique de l'oxymétrie (fig. 2). Il peut aussi être utile de placer les patients nécessitant des opioïdes parentéraux sous oxygénothérapie. ${ }^{23}$

Il est recommandé d'utiliser des techniques d'analgésie multimodales afin de minimiser l'administration postopératoire d'opioïdes. Ces techniques peuvent comprendre des blocs nerveux périphériques ou neuraxiaux avec cathéters dispensant des agents anesthésiques (sans opiö̈des) et la prise d'analgésiques permettant d'éviter l'utilisation d'opioïdes tels que les anti-inflammatoires non stéroïdiens, les inhibiteurs de la COX-2, la kétamine, l'acétaminophène, la prégabaline, la gabapentine, le tramadol, la dexmédétomidine, ${ }^{24}$ et la dexaméthasone. ${ }^{25}$ Il faut encourager les patients souffrant d'AOS connue et précédemment traités avec PAP à respecter le traitement de PAP après l'opération, et un traitement de PAP devrait être prescrit en période postopératoire. En particulier, la normalisation de l'architecture du sommeil et de l'IAH survient seulement la septième nuit postopératoire. ${ }^{26}$ Des recherches supplémentaires sur la prise en charge des patients souffrant d'AOS sont essentielles.

Aucun consensus n'existe quant à savoir si les patients souffrant d'AOS devraient recevoir leur congé de l'hôpital après une chirurgie. Les directives de l'ASA mettent en exergue que des chirurgies superficielles ou orthopédiques mineures réalisées avec des techniques locales ou régionales et les lithotrities peuvent être réalisées sur une base ambulatoire. ${ }^{7}$ Selon nous, les patients souffrant d'AOS légère (IAH 5-15) qui ont subi une chirurgie mineure, qui ne manifestent pas d'événements respiratoires récurrents en salle de réveil et qui n'ont pas besoin de doses élevées d'opioïdes oraux pour l'analgésie peuvent recevoir leur congé à la discrétion des médecins en charge (fig. 2). Les centres de chirurgie ambulatoire qui s'occupent de 
patients souffrant d'AOS devraient disposer d'accords de transfert vers des centres d'hospitalisation et des équipements nécessaires pour prendre en charge les situations imprévues associées à l'AOS.

\section{Conclusion}

Dans le contexte périopératoire, la combinaison dangereuse d'une prévalence élevée et d'un manque de diagnostic font de l'AOS un ennemi redoutable. Il est connu que l'AOS est associée à une augmentation des complications et de la morbidité postopératoire. Si l'on exerce un dépistage minutieux et de la vigilance en période préopératoire avec une stratification des risques pour les patients souffrant d'AOS connue ou soupçonnée, il est possible de mettre en place des soins aux patients personnalisés et individualisés. Des algorithmes pratiques basés sur les meilleures données probantes actuelles et les opinions d'experts pourraient orienter les anesthésiologistes lors de la prise en charge périopératoire de ces patients vulnérables.

\section{Cas clinique}

M. Tremblay est un homme d'origine caucasienne de 60 ans qui se présente avec des antécédents de douleur au genou droit et de difformité. Il éprouve également des difficultés s'il doit parcourir de longues distances à pied. Une consultation avec le chirurgien orthopédique et une radiographie du genou ont permis de confirmer le diagnostic d'ostéo-arthrite du genou droit. Une arthroplastie unilatérale du genou droit est prévue et le patient se présente à la clinique d'anesthésie pour une évaluation préopératoire. Il y a vingt ans, M. Tremblay a subi plusieurs opérations de la colonne lombaire en raison de «maux de dos », et il souffre encore d'une sciatalgie résiduelle dans la jambe gauche. Il a demandé à ne pas recevoir de rachianesthésie.

Au cours de l'évaluation préopératoire, vous remarquez plusieurs antécédents de comorbidités multiples. Parmi celles-ci, un accident vasculaire cérébral, de l'hyperlipidémie et une hypertension mal contrôlée. M. Tremblay prend de l'amlodipine et de l'aspirine sur une base régulière. Mme Tremblay est également présente en salle de consultation et elle ajoute que $\mathrm{M}$. Tremblay ronfle beaucoup et arrête de respirer quand il dort. En raison de ses ronflements sonores, ils font chambre à part. Pourtant, même ainsi, elle entend toujours les ronflements. M. Tremblay est aussi constamment fatigué pendant la journée. Aucune étude sur le sommeil n'a été réalisée par le passé.
À l'examen, M. Tremblay mesure $1,70 \mathrm{~m}$ et pèse $140 \mathrm{~kg}$. Sa tension artérielle au repos est de 180/95 mmHg et sa fréquence cardiaque est de $80 \bullet \mathrm{min}^{-1}$. La valeur de saturation d'oxygène mesurée par oxymétrie du pouls est de $92 \%$ à l'air ambiant. Son cou a $46 \mathrm{~cm}$ de circonférence. Les cicatrices des interventions rachidiennes antérieures sont notées. Le reste de l'examen ne révèle aucun autre élément significatif.

\section{Directives pour compléter le module de développement professionnel continu (DPC)}

1. Lisez les références en gras.

2. Rendez-vous à: https://www.cpass2.umontreal.ca/self assessmentprogram/, et choisissez le module actuel (La prise en charge de l'apnée du sommeil chez l'adulte: les algorithmes fonctionnels dans la période périopératoire).

3. Répondez aux questions à choix de réponses concernant le cas clinique.

4. Une fois que vous avez saisi toutes vos réponses, vous aurez accès aux explications d'experts pour tous les choix possibles.

5. Les participants peuvent réclamer un maximum de quatre heures de DPC pour un total de huit crédits sous la Section 3 du programme de DPC du Collège royal des médecins et chirurgiens du Canada.

Acknowledgements We wish to thank Dr Terence Davidson (San Diego Health Care System University of California, San Diego, California), Dr Janet Van Vlymen (Kingston General Hospital, Kingston, Ontario), Dr Stephen Cohen (Beth Israel Daeconess Medical Center, Boston, Massachusetts), Dr Norman Bolden (MetroHealth Medical Center, Cleveland, Ohio), Dr Michael Bishop (University of California, San Diego, California), and Dr Gregory Bryson (The Ottawa Hospital, Ottawa, Ontario) for sharing their expert opinion with us and for allowing us to peruse their institutional OSA protocols and policies.

Funding Departmental funding supported the submitted works.

Conflict of interest None declared.

\section{References}

1. Kryger MH. Diagnosis and management of sleep apnea syndrome. Clin Cornerstone 2000; 2: 39-47.

2. Chung F, Ward B, Ho J, Yuan H, Kayumov L, Shapiro C. Preoperative identification of sleep apnea risk in elective surgical patients using the Berlin questionnaire. J Clin Anesth 2007; 19: $130-4$.

3. Hwang D, Shakir N, Limann B, et al. Association of sleepdisordered breathing with postoperative complications. Chest 2008; 133: 1128-34. 
4. Liao P, Yegneswaran B, Vairavanathan S, Zilberman P, Chung F. Postoperative complications in patients with obstructive sleep apnea: a retrospective matched cohort study. Can J Anesth 2009; 56: 819-28.

5. Young T, Finn L, Peppard PE, et al. Sleep disordered breathing and mortality: eighteen-year follow-up of the Wisconsin sleep cohort. Sleep 2008; 31: 1071-8.

6. Marshall NS, Wong KK, Liu PY, Cullen SR, Knuiman MW, Grunstein RR. Sleep apnea as an independent risk factor for allcause mortality: the Busselton Health Study. Sleep 2008; 31: 1079-85.

7. Gross JB, Bachenberg KL, Benumof JL, et al. Practice guidelines for the perioperative management of patients with obstructive sleep apnea: a report by the American Society of Anesthesiologists Task Force on perioperative management of patients with obstructive sleep apnea. Anesthesiology 2006; 104: 1081-93.

8. Chung $\boldsymbol{S}$, Yuan $\boldsymbol{H}$, Chung $\boldsymbol{F}$. A systematic review of obstructive sleep apnea and its implications for anesthesiologists. Anesth Analg 2008; 107: 1543-63.

9. Fleetham J, Ayas N, Bradley D, et al. Canadian Thoracic Society guidelines: diagnosis and treatment of sleep disordered breathing in adults. Can Respir J 2006; 13: 387-92.

10. Iber C, Ancoli-Israel S, Cheeson A, et al. The AASM Manual for the Scoring of Sleep and Associated Events, Rules, Terminology and Technical Specifications. Westchester, IL: American Academy of Sleep Medicine; 2007

11. Netzer NC, Hoegel JJ, Loube D, et al. Prevalence of symptoms and risk of sleep apnea in primary care. Chest 2003; 124: 1406-14.

12. Chung F, Yegneswaran B, Liao P, et al. STOP Questionnaire: a tool to screen patients for obstructive sleep apnea. Anesthesiology 2008; 108: 812-21.

13. Chung F, Yegneswaran B, Liao P, et al. Validation of the Berlin questionnaire and American Society of Anesthesiologists checklist as screening tools for obstructive sleep apnea in surgical patients. Anesthesiology 2008; 108: 822-30.

14. Ramachandran SK, Josephs LA. A meta-analysis of clinical screening tests for obstructive sleep apnea. Anesthesiology 2009; 110: 928-39.

15. Chung $F$, Elsaid $H$. Screening for obstructive sleep apnea before surgery: why is it important? Curr Opin Anaesthesiol 2009; 22: 405-11.
16. Chung F, Yegneswaran B, Herrera F, Shenderey A, Shapiro CM. Patients with difficult intubation may need referral to sleep clinics. Anesth Analg 2008; 107: 915-20.

17. Gali B, Whalen FX, Schroeder D, Gay PC, Plevak DJ. Identification of patients at risk for postoperative respiratory complications using a preoperative obstructive sleep apnea screening tool and postanesthesia care assessment. Anesthesiology 2009; 110: 869-77.

18. Siyam MA, Benhamou D. Difficult endotracheal intubation in patients with sleep apnea syndrome. Anesth Analg 2002; 95: 1098-102.

19. American Society of Anesthesiologists Task Force on Management of the Difficult Airway. Practice guidelines for management of the difficult airway: an updated report by the American Society of Anesthesiologists Task Force on Management of the Difficult Airway. Anesthesiology 2003; 98: 1269-77

20. Sabate JM, Jouet P, Merrouche $M$, et al. Gastroesophaegeal reflux in patients with morbid obesity: a role of obstructive sleep apnea syndrome? Obes Surg 2008; 18: 1479-84.

21. Ovassapian A, Salem MR. Sellick's maneuver: to do or not do. Anesth Analg 2009; 109: 1360-2.

22. Bolden N, Smith CE, Auckley D, Makarski J, Avula R. Perioperative complications during use of an obstructive sleep apnea protocol following surgery and anesthesia. Anesth Analg 2008; 105: 1869-70.

23. Blake DW, Chia PH, Donnan G, Williams DL. Preoperative assessment for obstructive sleep apnoea and the prediction of postoperative respiratory obstruction and hypoxaemia. Anaesth Intensive Care 2008; 36: 379-84.

24. Bamgbade OA, Alfa JA. Dexmedetomidine anaesthesia for patients with obstructive sleep apnoea undergoing bariatric surgery. Eur J Anaesthesiol 2009; 26: 176-7.

25. Raghavendran $S$, Bagry $H$, Detheux $G$, Zhang X, Brouillette RT, Brown KA. An anesthetic management protocol to decrease respiratory complications after adenotonsillectomy in children with severe sleep apnea. Anesth Analg 2010; 110: 1093-101.

26. Chung F, Liao P, Fazel H, et al. Evolution of sleep pattern and sleep breathing disorders during first seven nights after surgery A pilot study. Sleep 2009; 32: 0667 (abstract) 